\title{
ABCD Analysis as Research Methodology in Company Case Studies
}

\author{
P. S. Aithal
}

Srinivas Institute of Management Studies, Srinivas University, Mangalore - 575 001, INDIA. E-Mail: psaithal@gmail.com

Type of the Paper: Research Policy.

Type of Review: Peer Reviewed.

Indexed in: OpenAIRE.

DOI: http://dx.doi.org/10.5281/zenodo.891621.

Google Scholar Citation: $\underline{\text { IJMTS }}$

\section{How to Cite this Paper:}

Aithal, P. S. (2017). ABCD Analysis as Research Methodology in Company Case Studies. International Journal of Management, Technology, and Social Sciences (IJMTS), 2(2), 40-54. DOI: http://dx.doi.org/10.5281/zenodo.891621.

International Journal of Management, Technology, and Social Sciences (IJMTS) A Refereed International Journal of Srinivas University, India.

(C) With Authors.

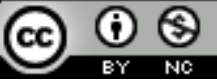

This work is licensed under a Creative Commons Attribution-Non Commercial 4.0 International License subject to proper citation to the publication source of the work.

Disclaimer: The scholarly papers as reviewed and published by the Srinivas Publications (S.P.), India are the views and opinions of their respective authors and are not the views or opinions of the SP. The SP disclaims of any harm or loss caused due to the published content to any party. 


\title{
ABCD Analysis as Research Methodology in Company Case Studies
}

\author{
P. S. Aithal \\ Srinivas Institute of Management Studies, Srinivas University, Mangalore - 575 001, INDIA. \\ E-Mail: psaithal@gmail.com
}

\begin{abstract}
Company analysis is a type of Case Study method among many types of Case study based Research Methods. While developing a Company Case study based on various issues in Management, the researcher can choose any company of any industry to study an issue or to solve a problem. Usually, a case analysis ends up with the observation of new performance pattern, interpretation of issues in the form of new information, or development of new suggestions to improve the system or to solve the problems optimally. Company analysis is considered to be a most powerful method to study new lessons required to identify, understand, and solve the problems in the process of managing and leading the organizations. Analysing business issues related to a company provides an opportunity to researchers to identify the kinds of situations, decisions, and dilemmas managers facing every day. Company analysis is a powerful tool in developing both research case study and teaching case study in business management subject. In this paper, we have discussed how ABCD Analysis as Research Methodology in company case analysis procedures in order to help the budding researchers while developing and analysing Company analysis as a Case study. In this paper, we have checked whether ABCD (Advantages, Benefits, Constraints, and Disadvantages) analysis framework can be used while analysing a company, how to consider various determinant issues of a company, selecting various affecting factors under these issues and identifying constituent critical elements for each construct using its elemental analysis technique, and the reasons to recommend the ABCD analysis framework in any kind of company analysis.
\end{abstract}

Keywords: Company analysis frameworks, ABCD analysis framework, Company issue analysis, Factor analysis, Elementary analysis, ABCD constructs.

\section{INTRODUCTION :}

Industry analysis and company analysis are considered as first steps in scholarly research [13]. Case studies on various issues identified in industries, industry sectors, public and private sector organizations, and companies are accepted as a method of explorative and empirical research methodology. Data collected from companies and industries using primary and secondary sources have to be analysed in systematic format to identify the issues or problems or to analyse the past, present, and future performance of the system. Out of many frameworks used for a company analysis, some popular frameworks are SWOT (strengths, weaknesses, opportunities, and threats), balanced scorecard and quality function deployment. Other frameworks such as Porter's Value Chain Analysis (VCA), facilitate the analysis of processes within a company but do not provide an easy mechanism to link these to high-level business objectives. relationships, and the underlying economic logic of an enterprise. A consistent method to analyze the structure, behaviour and the dynamics of a company business should allow identifying possible optimizations governing the business models, to assess the impact of innovative changes and to identify critical success factors before the changes are implemented within a particular 
environment. Various frameworks are used to analyze individual characteristics or organizational effectiveness \& strategies in a given environment which include SWOC analysis, PESTLE analysis, McKinsey 7S framework, ICDT model, Portor's five force model etc. Recently Aithal P. S. et al. [4] have proposed a simple but systematic analyzing technique for analysing operational, business, corporate, and international business issues in a company and hence it can be best suitable for Company analysis. The following table 1 lists various frameworks used in company analysis along with their inventors and the focuses on such analysis process.

Table 1 : Various frameworks used in company analysis along with their inventors and focuses on analysis.

\begin{tabular}{|c|c|c|c|}
\hline S. No. & $\begin{array}{l}\text { Analysis } \\
\text { Framework }\end{array}$ & Inventor & Focus \\
\hline 1 & $\begin{array}{l}\text { SWOT/SWOC } \\
\text { analysis [5] }\end{array}$ & $\begin{array}{l}\text { Albert Humphrey at the } \\
\text { Stanford Research Institute } \\
\text { during 1960. }\end{array}$ & $\begin{array}{lr}\text { Strength, } & \text { Weakness, } \\
\text { Opportunities, } & \text { and } \\
\text { Threats/Challenges. } & \\
\end{array}$ \\
\hline 2 & $\begin{array}{l}\text { PEST/PESTEL } \\
\text { analysis [6] }\end{array}$ & $\begin{array}{l}\text { Francis Aguilar at Harvard } \\
\text { Business School during } 1967 .\end{array}$ & $\begin{array}{lr}\text { Political, } & \text { Economic, } \\
\text { Sociological, } & \text { Technological, } \\
\text { Legal, \& Environmental analysis. }\end{array}$ \\
\hline 3 & $\begin{array}{l}\text { Six thinking hat } \\
\text { analysis [7] }\end{array}$ & Edward de Bono during 1985. & $\begin{array}{l}\text { Managing Blue, } \\
\text { Information White, } \\
\text { Emotions Red, } \\
\text { Discernment Black, Optimistic } \\
\text { response Yellow, } \\
\text { Creativity Green. }\end{array}$ \\
\hline 4 & $\begin{array}{l}\text { McKinsey } \\
\text { framework [8] }\end{array}$ & $\begin{array}{l}\text { Robert H. Waterman, } \\
\text { Jr. and Tom Peters of McKinsey } \\
\text { \& Company consulting firm in } \\
\text { the 1980s. }\end{array}$ & $\begin{array}{l}\text { Strategy, Structure, system, } \\
\text { Shared values, Skills, Style, and } \\
\text { Staff. }\end{array}$ \\
\hline 5 & $\begin{array}{l}\text { Balanced scorecard } \\
\text { [9] }\end{array}$ & $\begin{array}{l}\text { A.M. Schneiderman, at Analog } \\
\text { Devices in 1987. The framework } \\
\text { is popularized by Dr.Robert } \\
\text { Kaplan and David Norton in the } \\
\text { early 1990s. }\end{array}$ & $\begin{array}{l}\text { A management technique } \\
\text { designed to provide a view of an } \\
\text { organization from both internal } \\
\text { and external perspective. }\end{array}$ \\
\hline 6 & $\begin{array}{l}\text { Porter's Five Forces } \\
\text { analysis [10] }\end{array}$ & $\begin{array}{l}\text { Michael E. Porter of Harvard } \\
\text { Business School during } 1979 .\end{array}$ & $\begin{array}{l}\text { Five competitive forces on } \\
\text { business performance including } \\
\text { threat of new entrants, threat of } \\
\text { substitutes, bargaining power of } \\
\text { customers, bargaining power of } \\
\text { suppliers, and industry rivalry. }\end{array}$ \\
\hline 7 & $\begin{array}{l}\text { BCG's Growth share } \\
\text { matrix [11] }\end{array}$ & $\begin{array}{l}\text { Portfolio planning model } \\
\text { developed by Bruce D. } \\
\text { Henderson for the Boston } \\
\text { Consulting Group in } 1970 .\end{array}$ & $\begin{array}{l}\text { To rank the business units (or } \\
\text { products) on the basis of their } \\
\text { relative market shares and } \\
\text { growth rates into four categories } \\
\text { as Cash cows, Dogs, Question } \\
\text { marks, and Stars. }\end{array}$ \\
\hline 8 & $\begin{array}{l}\text { Value Chain analysis } \\
\text { [12] }\end{array}$ & $\begin{array}{l}\text { Michael E Porter of Harvard } \\
\text { Business School during } 1985 .\end{array}$ & Primary and Support activities \\
\hline
\end{tabular}


International Journal of Management, Technology, and Social

\begin{tabular}{|c|c|c|c|}
\hline 9 & Delta Model [13] & $\begin{array}{l}\text { Dean Wilde and Arnoldo C. Hax } \\
\text { at MIT during } 2003\end{array}$ & $\begin{array}{l}\text { Total customer solution, System } \\
\text { lock-in, Best product. }\end{array}$ \\
\hline 10 & $\begin{array}{l}\text { Resource Based } \\
\text { View Analysis [14] }\end{array}$ & $\begin{array}{l}\text { Barney, Jay B. Texas A\&M } \\
\text { University, during } 1991 .\end{array}$ & $\begin{array}{l}\text { Tangible resources, Intangible } \\
\text { resources, and organizational } \\
\text { capabilities. }\end{array}$ \\
\hline 11 & $\begin{array}{l}\text { Core competency } \\
\text { analysis [15] }\end{array}$ & $\begin{array}{l}\text { C. K. Prahalad and Gary Hamel } \\
\text { of University of Michigan } \\
\text { during 1990. }\end{array}$ & $\begin{array}{l}\text { Organization's } \\
\text { learning, particularly of how to } \\
\text { coordinate diverse production } \\
\text { skills and integrate multiple } \\
\text { technologies. }\end{array}$ \\
\hline 12 & $\begin{array}{l}\text { Heptalysis } \\
\text { Analysis [16] }\end{array}$ & Pejman Makhfi during 2005. & $\begin{array}{l}\text { Market opportunity, } \\
\text { Product/solution, } \\
\text { Execution plan, } \\
\text { Financial engine, } \\
\text { Human capital, } \\
\text { Potential return, and } \\
\text { Margin of safety. }\end{array}$ \\
\hline 13 & $\begin{array}{l}\text { MOST /VMOST } \\
\text { analysis [17] }\end{array}$ & $\begin{array}{l}\text { Rakesh K. Sondhi, BMC Global } \\
\text { Services Ltd. U.K., in } 1999 .\end{array}$ & $\begin{array}{l}\text { Vision/Mission, Objectives, } \\
\text { Strategies, and Tactical. }\end{array}$ \\
\hline 14 & $\begin{array}{l}\text { CATWOE analysis } \\
\text { [18] }\end{array}$ & $\begin{array}{l}\text { David Smyth, and Peter } \\
\text { Checkland of University of } \\
\text { Lancaster, England in 1975. }\end{array}$ & $\begin{array}{l}\text { Customers, Actors, } \\
\text { Transformation process, World } \\
\text { view, Owner, Environmental } \\
\text { constraints. }\end{array}$ \\
\hline 15 & $\begin{array}{l}\text { VPEC-T analysis } \\
\text { [19] }\end{array}$ & $\begin{array}{l}\text { David Hunt, \& Liz Bacon, } \\
\text { Computing and Mathematical } \\
\text { Sciences department, University } \\
\text { of Greenwich, during } 2009 .\end{array}$ & $\begin{array}{l}\text { Values, Policies, } \\
\text { Eventent, and Trust. }\end{array}$ \\
\hline 16 & $\begin{array}{l}\text { ICDT Model for E- } \\
\text { business [20] }\end{array}$ & $\begin{array}{l}\text { Developed by Albert Angehrn at } \\
\text { INSEAD, France during } 1997 .\end{array}$ & $\begin{array}{lr}\text { Segmentation of the virtual } \\
\text { 'marketspace' into four } & \text { distinct } \\
\text { areas: Information } & \text { Space, } \\
\text { Communication } & \text { Space, } \\
\begin{array}{l}\text { Distribution Space, } \\
\text { Transaction Space. }\end{array} & \\
\end{array}$ \\
\hline 17 & ABCD Analysis [4] & $\begin{array}{l}\text { Aithal P. S. et al. of SIMS, India } \\
\text { in } 2015 \text {. }\end{array}$ & 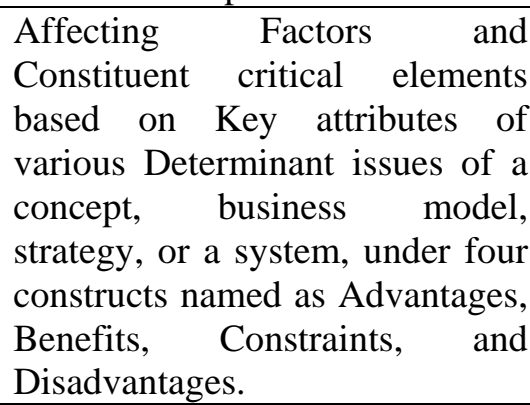 \\
\hline
\end{tabular}

\section{ABOUT ABCD ANALYSIS :}

ABCD framework can be used to analyze the individual characteristics, system characteristics, effectiveness of a concept or idea, effectiveness of a strategy while studying the business value in the society [4]. The individual characteristics or organizational effectiveness \& strategies in a given environment can be also studied using either SWOT analysis, SWOC analysis, PEST analysis, McKinsey 7S framework, ICDT model, Portor's five force model etc. ABCD analysis framework is recently introduced business analysis framework during the year 
2015 and is suitable for analysing business concepts, business systems, technology, business models or business idea in terms of determining various factors for chosen determinant issues under four constructs called advantages, benefits, constraints, and disadvantages. ABCD analysis framework can be also used to analyse a given resource (material, machine, information, or human resource) based on its usage for a purpose in the society. In the qualitative analysis using ABCD framework, the concept/system/ strategy/ techno logy/model/idea/ resource is further analysed by identifying constitutional critical elements. In the quantitative analysis using ABCD framework [4], the appropriate score/weightage can be given to each constituent critical elements under each construct, through empirical research, the total score is calculated for each construct and by evaluating the scores, the concept/idea/system/technology/strategy can be accepted or rejected. Thus ABCD analysis framework can be used as a research tool in these areas and is a simple but systematic analyzing technique for company analysis by considering its business models/ systems/ concepts/ ideas/technology/strategy/material analysis. ABCD analysis framework is used to analyse various systems/concepts/processes like Working from Home - an e-business model [21], Black ocean strategy [22], Higher Education Stage Model [23], National Assessment and Accreditation Council (NAAC) accreditation process [24], Private University System in India [25], Study of New National Institutional Ranking Framework (NIRF) System [26], ABC organizational research performance model [27], Elemental and factor analysis of the usage of dye-doped polymer films for photonic applications [28], Online Industry Oriented Campus (OIOC) Placement Model [29], Six thinking hats model for lateral thinking [30], Analysis of 'Theory A' on Organizational Performance [31], analysis of new Research Indices [32-33], etc.

While applying ABCD framework [34] for company analysis, one has to be careful in identifying major issues governing/ related to that company. The issues related to the company such as organization, operation, administration, actors within the organization and dependents on the organization, the technology, and the business environment. Once the determinant issues of the company are identified, the various factors affecting these issues have to be discovered through focus group discussion under four identified constructs advantages, benefits, constraints and disadvantages of ABCD framework. Finally, the constituent critical elements for each affecting factors should be identified and listed under ABCD constructs. The importance of the company analysis can be discussed based on comparing constructs which are based on analyzing the factors affecting in each construct. In quantitative analysis scheme, the weightage to each factor affecting various constructs can be given based on the importance of identified constituent critical elements. By comparing the weightage, one can decide the usefulness of the issue discussed.

\section{OBJECTIVES OF THE STUDY :}

(1) To study whether ABCD analysis framework can be used while analysing a company belonging to any type of industry/industry sector.

(2) To discuss how ABCD analysis framework can be used to do company analysis in case study based research.

(3) To find various possible issues in a company to consider as determinant issues in ABCD analysis framework.

(4) To determine various affecting factors under these issues based on ABCD constructs using its factor analysis methodology.

(5) To identify constituent critical elements for each construct using its elemental analysis technique.

(6) Reasons to recommend the ABCD analysis framework in any kind of company analysis.

\section{ABCD ANALYSIS FRAMEWORK AS RESEARCH METHODOLOGY FOR COMPANY ANALYSIS :}

As per table 1, various analysis methods and frameworks can be used in company analysis while studying company's internal abilities of doing business to fulfil its objectives, company's external environmental effects while doing its 
business, to study company's business model, company's operations and business strategy, company's new product/services, company's ability to expand its business, company's concept of managing its human resource, etc. Some of the issues related to the company analysis which can be discussed using suitable analysis frameworks are listed in table 2.

Table 2 : Various Company issues and the type of analysis frameworks to be used.

\begin{tabular}{|c|c|c|}
\hline S. No. & Issues in company analysis & Type of Analysis \\
\hline 1 & $\begin{array}{l}\text { Internal abilities to do business to } \\
\text { fulfill its objectives }\end{array}$ & $\begin{array}{l}\text { SWOC analysis, Balanced scorecard, McKinsey 7- } \\
\text { S framework, ABCD analysis. }\end{array}$ \\
\hline 2 & $\begin{array}{l}\text { External environmental effect while } \\
\text { doing its business }\end{array}$ & $\begin{array}{l}\text { PESTLE analysis, Balanced scorecard, ABCD } \\
\text { analysis, Porter's Five Forces analysis. }\end{array}$ \\
\hline 3 & To study business model & $\begin{array}{l}\text { CATWOE analysis, Porter's Five Forces analysis, } \\
\text { ABCD analysis. }\end{array}$ \\
\hline 4 & $\begin{array}{l}\text { To study operations and business } \\
\text { strategy }\end{array}$ & $\begin{array}{l}\text { MOST /VMOST analysis, Porter's Five Forces } \\
\text { analysis, ABCD analysis. }\end{array}$ \\
\hline 5 & To study new product/services & $\begin{array}{l}\text { Heptalysis Analysis, ABCD analysis, Porter's Five } \\
\text { Forces analysis. }\end{array}$ \\
\hline 6 & $\begin{array}{l}\text { Company's ability to expand its } \\
\text { business }\end{array}$ & $\begin{array}{l}\text { ABCD analysis, PESTLE analysis, ICDT Model for } \\
\text { E-business, CATWOE analysis, Core competency } \\
\text { analysis, BCG's Growth share matrix, SWOC } \\
\text { analysis. }\end{array}$ \\
\hline 7 & Managing its human resource & ABCD analysis, Six thinking hats analysis, \\
\hline 8 & Organizational Decisions & $\begin{array}{l}\text { ABCD analysis, Six thinking hats analysis, VPEC- } \\
\text { T analysis, SWOT/SWOC analysis. }\end{array}$ \\
\hline 9 & $\begin{array}{l}\text { Organizational improvement and } \\
\text { change }\end{array}$ & Balanced scorecard, SWOT/SWOC analysis. \\
\hline 10 & $\begin{array}{l}\text { Competitive forces that influence } \\
\text { profitability }\end{array}$ & $\begin{array}{l}\text { Porter's Five Forces analysis, Heptalysis } \\
\text { Analysis. }\end{array}$ \\
\hline 11 & $\begin{array}{l}\text { Investments in numerous business } \\
\text { units/subsidiaries }\end{array}$ & GE-McKinsey nine-box matrix. \\
\hline 12 & Product portfolio & BCG's Growth share matrix, ABCD analysis. \\
\hline 13 & $\begin{array}{l}\text { Improvements in the ability of } \\
\text { innovations \& uniqueness }\end{array}$ & $\begin{array}{l}\text { Core competency analysis, ABCD analysis, } \\
\text { SWOT/SWOC analysis. }\end{array}$ \\
\hline 14 & Organizational values & $\begin{array}{l}\text { Value Chain analysis, VPEC-T analysis, VPEC-T } \\
\text { analysis, Resource Based View Analysis. }\end{array}$ \\
\hline 15 & Company Strategy & $\begin{array}{l}\text { Delta Model, Porter's Five Forces analysis, } \\
\text { MOST/VMOST analysis, Core competency } \\
\text { analysis, BCG's Growth share matrix, McKinsey 7- } \\
\text { S framework, ABCD analysis. }\end{array}$ \\
\hline 16 & Company Asset & $\begin{array}{l}\text { Resource Based View Analysis, Core competency } \\
\text { analysis. }\end{array}$ \\
\hline 17 & $\begin{array}{l}\text { In-depth analysis of early stage } \\
\text { businesses/ventures }\end{array}$ & $\begin{array}{l}\text { Heptalysis analysis, Value Chain analysis, Core } \\
\text { competency analysis, Porter's Five Forces analysis. }\end{array}$ \\
\hline 18 & Internal environmental analysis & MOST analysis, SWOT/SWOC analysis. \\
\hline 19 & $\begin{array}{l}\text { Business perspectives based on } \\
\text { people involvement }\end{array}$ & $\begin{array}{l}\text { CATWOE analysis, Core competency analysis, } \\
\text { VPEC-T analysis, Heptalysis } \\
\text { Analysis. }\end{array}$ \\
\hline
\end{tabular}


International Journal of Management, Technology, and Social

\begin{tabular}{|l|l|l|}
\hline 20 & $\begin{array}{l}\text { Expectations of multiple parties } \\
\text { having different views of a system }\end{array}$ & $\begin{array}{l}\text { VPEC-T analysis, Heptalysis } \\
\text { Analysis. }\end{array}$ \\
\hline 21 & $\begin{array}{l}\text { Business related to online business } \\
\text { strategies using the Internet (E- } \\
\text { business) }\end{array}$ & ICDT Model for E-business, ABCD analysis. \\
\hline 22 & $\begin{array}{l}\text { Financial performance \& Financial } \\
\text { health }\end{array}$ & $\begin{array}{l}\text { Balance Sheet Analysis, Heptalysis } \\
\text { Analysis, BCG's Growth share matrix. }\end{array}$ \\
\hline
\end{tabular}

\subsection{Determinant Issues:}

Based on the topic of company case analysis which may be the business model of the company, the products/services of the company, the company strategy in doing business, the resources used and manipulated in a company, the new concepts/ideas used in the company to support its business, the decisions are taken by managers/leaders to solve problems in a company, the determinant issues can be identified and listed. Identifying various determinant issues in a company analysis is a challenging and interesting job. The researchers can identify major determinant issues through their intuition using their knowledge, skills, and experience in a team, or using focused group discussions [35-40]. Some of the possible determinant issues in a company analysis using ABCD framework are listed in table 3.

Table 3 : Various determinant issues in Company analysis.

\begin{tabular}{|c|c|c|}
\hline $\begin{array}{l}\text { S. } \\
\text { No. }\end{array}$ & $\begin{array}{l}\text { Type of Company } \\
\text { based on function }\end{array}$ & Determinant Issues \\
\hline 1 & Production & $\begin{array}{l}\text { Organizational issues, Industry Issues, Operational Issues, Employees } \\
\text { Issues, Administrative issues, Quality Issues. Technological issues, } \\
\text { Strategic Issues, Environmental \& Social issues etc. }\end{array}$ \\
\hline 2 & Marketing & $\begin{array}{l}\text { Organizational issues, Industry Issues, Quality Issues, Employees } \\
\text { Issues, Administrative issues, Technological issues, Strategic Issues, } \\
\text { Sales service Issues, Environmental \& Social issues etc. }\end{array}$ \\
\hline 3 & Service & $\begin{array}{l}\text { Operational Issues, Input Issues, Output Issues, Performance Issues, } \\
\text { Quality Issues, Users Issues, Technological Issues, Environmental \& } \\
\text { Social Issues, Issues on Innovative Processes etc. }\end{array}$ \\
\hline 4 & Financial & $\begin{array}{l}\text { Organizational issues, Industry Issues, Investors Issues, Security } \\
\text { Issues, Performance Issues, Customers Issues, CSR issues, } \\
\text { Profitability Issues etc. }\end{array}$ \\
\hline 5 & Consultancy & $\begin{array}{l}\text { Professional Issues, Business Issues, Idea Implementation Issues, } \\
\text { Service Issues, Stakeholders Issues, Administrative issues, } \\
\text { Environmental \& Social issues etc. }\end{array}$ \\
\hline 6 & Virtual online & $\begin{array}{l}\text { Organizational issues, Investors Issues, Security Issues, Business } \\
\text { Model Issues, Sales \& service Issues, Stakeholders Issues, } \\
\text { Technological Issues, }\end{array}$ \\
\hline 7 & Education & $\begin{array}{l}\text { Organizational issues, Student Progression } \\
\text { development Issues, Societal \& } \\
\text { Other stakeholders Issues, Governance and Leadership Issues, } \\
\text { Innovations and Best Practices. }\end{array}$ \\
\hline 8 & IT \& ITES company & $\begin{array}{l}\text { Organizational Issues, Business Issues, Idea Implementation Issues, } \\
\text { Operational Issues, Stakeholders Issues, Administrative issues, Users } \\
\text { Issues, Technological issues, Environmental \& Social issues etc. }\end{array}$ \\
\hline 9 & Idea and Concept & $\begin{array}{l}\text { Organizational Issues, Business Issues, Idea Implementation Issues, } \\
\text { Operational Issues, Stakeholders Issues, Administrative issues, Users }\end{array}$ \\
\hline
\end{tabular}


International Journal of Management, Technology, and Social

Issues, Technological issues, Environmental \& Social issues etc.

factors under each of the four constructs

\subsection{Key Attributes :}

The company issues are discussed and analysed based on identifying some key attributes to each and every determinant issues. Key attributes are prominent attributes or characteristics of the determinant issues for deciding the affecting advantages, benefits, constraints and disadvantages. Some of the key attributes for identified company issues are listed in table 4. Only prominent attributes of the company determinant issues should be considered to restrict the length of the analysis.

Table 4 : Various Key Attributes in Company analysis [4].

\begin{tabular}{|c|c|c|}
\hline S. No. & Company Issues & Key Attributes \\
\hline 1 & Organization & $\begin{array}{l}\text { Growth saga, leadership, industry type, culture, } \\
\text { vision, mission, objectives, ideology etc. }\end{array}$ \\
\hline 2 & Business & $\begin{array}{l}\text { Survival strategy with limited resources, business } \\
\text { model, nature of products and services, } \\
\text { stakeholders, turnaround strategy in business etc. }\end{array}$ \\
\hline 3 & Industry & $\begin{array}{l}\text { Nature of industry, challenges, business expansion, } \\
\text { changes in future demand, competitors \& } \\
\text { collaborators etc. }\end{array}$ \\
\hline 4 & Geographical Location & $\begin{array}{l}\text { Innovation in technology, connectivity, business } \\
\text { model, raw material and skilled labour availability, } \\
\text { access to the customers, etc. }\end{array}$ \\
\hline 5 & Competitors & $\begin{array}{l}\text { Product, quality, strategy, competitiveness, } \\
\text { technology, business channel, after sales service } \\
\text { etc. }\end{array}$ \\
\hline 6 & Product/Service & $\begin{array}{l}\text { Demand, new product, product features, } \\
\text { differentiation, value addition etc. }\end{array}$ \\
\hline 7 & Stakeholders & Feedback, Improving business process \\
\hline 8 & Suppliers & $\begin{array}{l}\text { Switching cost based information system, Supplier } \\
\text { retention strategy, philanthropy based expansion } \\
\text { etc. }\end{array}$ \\
\hline 9 & Business Strategy & $\begin{array}{l}\text { Identification of present strategy, type of turn- } \\
\text { around strategy used if any, Decision with Risk, } \\
\text { position of the company in strategic grid, etc. }\end{array}$ \\
\hline 10 & Corporate Strategy & $\begin{array}{l}\text { Investment decisions, new products/services, } \\
\text { business expansion \& collaborative strategies, } \\
\text { growth strategies, etc. }\end{array}$ \\
\hline 11 & Operational Strategy & $\begin{array}{l}\text { Best practices, quality \& time management, } \\
\text { Innovation in production \& operations, automation, } \\
\text { wastage policy, resource utilization etc. }\end{array}$ \\
\hline 12 & Technology & $\begin{array}{l}\text { Growth strategy, product/service innovations, } \\
\text { technology management, etc. }\end{array}$ \\
\hline 13 & Finance & $\begin{array}{l}\text { Transformation strategy, Investment decisions, } \\
\text { fundraising, cash flow, financial controls, liquidity } \\
\text { etc. }\end{array}$ \\
\hline 14 & Market & $\begin{array}{l}\text { Marketing strategy, advertisement skills, market } \\
\text { expansion, focus on niche segment etc. }\end{array}$ \\
\hline 15 & Human Resource Management & Team work, retaining talents, \\
\hline
\end{tabular}


International Journal of Management, Technology, and Social

\begin{tabular}{|c|c|c|}
\hline & & $\begin{array}{l}\text { satisfaction, employee involvement, remuneration } \\
\text { strategy, employee accountability etc. }\end{array}$ \\
\hline 16 & Innovations & $\begin{array}{l}\text { Brand extension, marketing strategy, } \\
\text { product/service innovation, business model } \\
\text { innovation, best practices in business, customer } \\
\text { value creation, etc. }\end{array}$ \\
\hline 17 & Sustainability & $\begin{array}{l}\text { Business Challenges, turnaround strategy, } \\
\text { managing resources, recycling strategy, emission } \\
\text { control and green management strategies, retaining } \\
\text { customers, gaining new customers, low cost - } \\
\text { differentiation mixed strategy etc. }\end{array}$ \\
\hline 18 & Profit / Loss & $\begin{array}{l}\text { Business performance, long term profit, employee } \\
\text { performance, innovative products/services, IT } \\
\text { Innovation, new business models \& supply chain } \\
\text { channels etc. }\end{array}$ \\
\hline 19 & Business Model & $\begin{array}{l}\text { Online business models, e-payment, after sales } \\
\text { service, repositioning of Products/Services, } \\
\text { innovations in business models etc. }\end{array}$ \\
\hline 20 & Collaborations & $\begin{array}{l}\text { Cost control, quality improvement, outsourcing } \\
\text { decisions, Business Innovations, business } \\
\text { expansion, globalization etc. }\end{array}$ \\
\hline 21 & Internationalization & $\begin{array}{l}\text { Business expansion, standardized products, ICT } \\
\text { Innovation, technology transfer, collaboration, etc. }\end{array}$ \\
\hline 22 & Automation of processes & $\begin{array}{l}\text { Business Innovation, investment on research \& } \\
\text { development, inventory management etc. }\end{array}$ \\
\hline 23 & Business Expansion & $\begin{array}{l}\text { Creating demand, enhancing production, } \\
\text { international markets \& collaborations, new } \\
\text { business models, online services etc. }\end{array}$ \\
\hline 24 & Profitability & $\begin{array}{l}\text { Products innovation, pricing, value creation HR } \\
\text { efficiency, low cost player etc. }\end{array}$ \\
\hline 25 & Merger \& Acquisition & $\begin{array}{l}\text { Acquisition based turnaround strategy, quality } \\
\text { improvements through mergers, improved business } \\
\text { performance etc. }\end{array}$ \\
\hline 26 & CSR & $\begin{array}{l}\text { Social service, environmental cleanliness, usage of } \\
\text { renewable energy, job creation, stakeholders } \\
\text { empowerment activities, neighborhood village } \\
\text { adoption etc. }\end{array}$ \\
\hline 27 & Environmental sustainability & $\begin{array}{l}\text { Environmental Strategy, environmental cleanliness, } \\
\text { usage of renewable energy, resource recycling etc. }\end{array}$ \\
\hline 28 & Productivity & $\begin{array}{l}\text { Product Innovation, quality maintenance, Just in } \\
\text { production, production efficiency, automation, etc. }\end{array}$ \\
\hline 29 & Management decisions & $\begin{array}{l}\text { Product innovation, business expansion, hiring, } \\
\text { business plan etc. }\end{array}$ \\
\hline 30 & Research \& Development & $\begin{array}{l}\text { Innovations in production processes, marketing, and } \\
\text { business strategy. }\end{array}$ \\
\hline
\end{tabular}




\subsection{Framework for ABCD Constructs}

The framework allows the researchers to identify the affecting factors for different key attributes under four constructs as shown in table
Depending on the number of determinant issues and corresponding key attributes, the number of affecting factors may vary.

Table 5 : Framework for ABCD Constructs for three determinant issues and three key constructs

\begin{tabular}{|c|c|c|c|c|c|c|}
\hline $\begin{array}{l}\text { S. } \\
\text { No. }\end{array}$ & $\begin{array}{l}\text { Determinant } \\
\text { Issues }\end{array}$ & $\begin{array}{l}\text { Key Attribute } \\
\text { of a } \\
\text { determinant } \\
\text { issue }\end{array}$ & Advantages & Benefits & Constraints & Disadvantages \\
\hline \multirow[t]{3}{*}{1} & \multirow[t]{3}{*}{$\begin{array}{l}\text { Determinant } \\
\text { Issue } 1\end{array}$} & $\begin{array}{l}\text { Key Attribute } \\
1\end{array}$ & $\begin{array}{l}\text { Advantage } \\
\text { of key } \\
\text { attribute } 1 \\
\end{array}$ & $\begin{array}{l}\text { Benefit of } \\
\text { key } \\
\text { attribute } 1\end{array}$ & $\begin{array}{l}\text { Constraint of } \\
\text { key attribute } \\
1\end{array}$ & $\begin{array}{l}\text { Disadvantage of } \\
\text { key attribute } 1\end{array}$ \\
\hline & & $\begin{array}{l}\text { Key Attribute } \\
2\end{array}$ & $\begin{array}{l}\text { Advantage } \\
\text { of key } \\
\text { attribute } 2 \\
\end{array}$ & $\begin{array}{l}\text { Benefit of } \\
\text { key } \\
\text { attribute } 2\end{array}$ & $\begin{array}{l}\text { Constraint of } \\
\text { key attribute } \\
2\end{array}$ & $\begin{array}{l}\text { Disadvantage of } \\
\text { key attribute } 2\end{array}$ \\
\hline & & $\begin{array}{l}\text { Key Attribute } \\
3\end{array}$ & $\begin{array}{l}\text { Advantage } \\
\text { of key } \\
\text { attribute } 3 \\
\end{array}$ & $\begin{array}{l}\text { Benefit of } \\
\text { key } \\
\text { attribute } 3\end{array}$ & $\begin{array}{l}\text { Constraint of } \\
\text { key attribute } \\
3\end{array}$ & $\begin{array}{l}\text { Disadvantage of } \\
\text { key attribute } 3\end{array}$ \\
\hline \multirow[t]{3}{*}{2} & \multirow[t]{3}{*}{$\begin{array}{l}\text { Determinant } \\
\text { Issue } 2\end{array}$} & $\begin{array}{l}\text { Key Attribute } \\
1\end{array}$ & $\begin{array}{l}\text { Advantage } \\
\text { of key } \\
\text { attribute } 1 \\
\end{array}$ & $\begin{array}{l}\text { Benefit of } \\
\text { key } \\
\text { attribute } 1\end{array}$ & $\begin{array}{l}\text { Constraint of } \\
\text { key attribute } \\
1\end{array}$ & $\begin{array}{l}\text { Disadvantage of } \\
\text { key attribute } 1\end{array}$ \\
\hline & & $\begin{array}{l}\text { Key Attribute } \\
2\end{array}$ & $\begin{array}{l}\text { Advantage } \\
\text { of key } \\
\text { attribute } 2\end{array}$ & $\begin{array}{l}\text { Benefit of } \\
\text { key } \\
\text { attribute } 2\end{array}$ & $\begin{array}{l}\text { Constraint of } \\
\text { key attribute } \\
2\end{array}$ & $\begin{array}{l}\text { Disadvantage of } \\
\text { key attribute } 2\end{array}$ \\
\hline & & $\begin{array}{l}\text { Key Attribute } \\
3\end{array}$ & $\begin{array}{l}\text { Advantage } \\
\text { of key } \\
\text { attribute } 3 \\
\end{array}$ & $\begin{array}{l}\text { Benefit of } \\
\text { key } \\
\text { attribute } 3\end{array}$ & $\begin{array}{l}\text { Constraint of } \\
\text { key attribute } \\
3\end{array}$ & $\begin{array}{l}\text { Disadvantage of } \\
\text { key attribute } 3\end{array}$ \\
\hline \multirow[t]{3}{*}{3} & \multirow[t]{3}{*}{$\begin{array}{l}\text { Determinant } \\
\text { Issue } 3\end{array}$} & $\begin{array}{l}\text { Key Attribute } \\
1\end{array}$ & $\begin{array}{l}\text { Advantage } \\
\text { of key } \\
\text { attribute } 1 \\
\end{array}$ & $\begin{array}{l}\text { Benefit of } \\
\text { key } \\
\text { attribute } 1\end{array}$ & $\begin{array}{l}\text { Constraint of } \\
\text { key attribute } \\
1\end{array}$ & $\begin{array}{l}\text { Disadvantage of } \\
\text { key attribute } 1\end{array}$ \\
\hline & & $\begin{array}{l}\text { Key Attribute } \\
2\end{array}$ & $\begin{array}{l}\text { Advantage } \\
\text { of key } \\
\text { attribute } 2 \\
\end{array}$ & $\begin{array}{l}\text { Benefit of } \\
\text { key } \\
\text { attribute } 2\end{array}$ & $\begin{array}{l}\text { Constraint of } \\
\text { key attribute } \\
2\end{array}$ & $\begin{array}{l}\text { Disadvantage of } \\
\text { key attribute } 2\end{array}$ \\
\hline & & $\begin{array}{l}\text { Key Attribute } \\
3\end{array}$ & $\begin{array}{l}\text { Advantage } \\
\text { of key } \\
\text { attribute } 3 \\
\end{array}$ & $\begin{array}{l}\text { Benefit of } \\
\text { key } \\
\text { attribute } 3\end{array}$ & $\begin{array}{l}\text { Constraint of } \\
\text { key attribute } \\
3\end{array}$ & $\begin{array}{l}\text { Disadvantage of } \\
\text { key attribute } 3\end{array}$ \\
\hline
\end{tabular}

key issues/key attributes, the number of

\subsection{Factors Affecting:}

Various affecting factors under the identified issues in the previous section should be determined based on the constructs of Advantages, Benefits, Constraints, and Disadvantages using its factor analysis methodology for every key attribute and are listed in the form of a table as shown in Table 5. Depending on the number of determinant issues on a given subject of analysis, and a number of affecting factors may vary. In case of quantitative analysis, these affecting factors can be ranked by giving scores to them based on their weightge, which can be calculated using focused group method.

\subsection{Critical Constituent Elements:}

As a part of the further analysis, the constituent critical elements for each construct using its elemental analysis technique. For each ABCD construct, the critical constituent elements have 
to be identified and listed so that four additional tables for four sets of constituent critical elements can be developed. Further, these critical constituent elements can be ranked based on their score/weightage in Quantitative analysis under each ABCD constructs to get quantitative result on the importance of each construct. The results on the sum of the total scores of advantages (construct $A$ ), the sum of the total scores of benefits (construct $B$ ), the sum of the total scores of constraints (construct $\mathrm{C}$ ), and the sum of the total scores of disadvantages (construct D) have to be compared. The total sum of the scores of advantages and benefits should be more than the total sum of the scores of constraints and disadvantages, for real systems.

\section{ABCD LISTING FOR COMPANY} ANALYSIS :

In qualitative company analysis, after choosing various issues to be analysed in a company, one can list important advantages, benefits, constraints, and disadvantages of every identified determinant issues. This will also give the basic idea and can be considered as the predefined condition for ABCD analysis and is named as ABCD listing [41-51]. For example, the format of ABCD listing for different determinant issues (Issue 1 to Issue 3 ) is shown below :

\section{Company Issue 1:}

Advantages of Issue 1:

- Advantage 1

- Advantage 2

- Advantage 3

- Advantage 4

Benefits of Issue 1:

- $\quad$ Benefit 1

- Benefit 2

- Benefit 3

- Benefit 4

Constraints of Issue 1:

- Constraint 1

- Constraint 2

- Constraint 3

- Constraint 4
- Disadvantage 2

- Disadvantage 3

- Disadvantage 4

Company Issue 2:

Advantages of Issue 2:

- Advantage 1

- Advantage 2

- Advantage 3

- Advantage 4

Benefits of Issue 2 :

- Benefit 1

- Benefit 2

- Benefit 3

- Benefit 4

Constraints of Issue 2 :

- Constraint 1

- Constraint 2

- Constraint 3

- Constraint 4

Disadvantages of Issue 2 :

- Disadvantage 1

- Disadvantage 2

- Disadvantage 3

- Disadvantage 4

Company Issue 3 :

Advantages of Issue 3 :

- Advantage 1

- Advantage 2

- Advantage 3

- Advantage 4

Benefits of Issue 3 :

- Benefit 1

- Benefit 2

- Benefit 3

- Benefit 4

Constraints of Issue 3:

- Constraint 1

- Constraint 2

- Constraint 3

- Constraint 4

Disadvantages of Issue 3:

- Disadvantage 1

- Disadvantage 2

- Disadvantage 3

- Disadvantage 4

Disadvantages of Issue 1:

- Disadvantage 1 


\section{REASONS TO RECOMMEND ABCD ANALYSIS USING ABCD FRAMEWORK :}

ABCD analysis framework can be used for any kind of company case study. Unlike SWOT which allows internal company analysis, and PESTLE, which allows external company analysis, ABCD analysing framework allows the researcher to analyse any issues related to both internal and external to its business. As seen in table 2, out of 22 set of issues identified in various sections of company business, 12 set of issues can be analysed using $A B C D$ analysing framework. This analysis framework being simple and straight forward, can be used to study many company issues/problems to find a suitable solution through simplifying the issues/problems by identifying the affecting factors through the factor analysis and critical constituent elements through elemental analysis. Analysing business models, business systems, business strategy, business concepts and ideas, products \& services of a company, future expansion plans of a company etc. through ABCD constructs allows the readers to identify and understand the problems from various stakeholders point of view so that an optimum solution can be developed. Thus using ABCD analysis framework in suitable depth either qualitative listing, qualitative analysis, or quantitative analysis of identified issues is recommended in company case study as a research methodology.

\section{CONCLUSION :}

(1) Based on above discussions, it is found that ABCD analysis framework can be used while analysing a company belonging to any type of industry/industry sector.

(2) It is also discussed how ABCD analysis framework can be used to do company analysis in case study based research.

(3) Various possible issues should be identified for a company under consideration and based on the objectives, different determinant issues can be identified as per the ABCD analysis framework.

(4) It is also studied how various affecting factors can be determined under the identified issues based on ABCD constructs using factor analysis methodology.

(5) It is also understood how various Constituent critical elements for each construct can be determined using its elemental analysis technique.

(6) Finally, the reasons to recommend the ABCD analysis framework in any kind of company analysis are also determined and argued that using ABCD analysis framework in suitable depth either qualitative listing, qualitative analysis, or quantitative analysis of identified issues can be a research methodology in company case studies.

\section{REFERENCES :}

[1] Aithal, P. S., (2017). Company Analysis The Beginning Step for Scholarly Research. International Journal of Case Studies in Business, IT and Education (IJCSBE), 1(1), 1-18. DOI: http://dx.doi.org/10.5281/zenodo.573769.

[2] Aithal, P. S. (2017). An Effective Method of Developing Business Case Studies based on Company Analysis, International Journal of Engineering Research and Modern Education (IJERME), 2(1), 16-27. DOI: http://dx.doi. org/10.5281/ZENODO.400579.

[3] Aithal, P. S. (2017). Industry Analysis - The First Step in Business Management Scholarly Research. International Journal of Case Studies in Business, IT and Education (IJCSBE), 2(1), 1-13. DOI: http://dx.doi.org/10.5281/zenodo .810347.

[4] Aithal, P. S., (2016). Study on ABCD Analysis Technique for Business Models, Business Strategies, Operating Concepts \& Business Systems. International Journal in Management and Social Science, 4(1), 98115. DOI http://doi.org/10.5281/zenodo.161137.

[5] Humphrey, A. S. (2005). SWOT analysis. Long Range Planning, 30, 46-52.

[6] Aguilar, Francis J. (1967), Scanning the business environment. New York, Macmillan. pp. 1-237.

[7] De Bono, E., \& De Bono, E. (1999). Six 
thinking hats (Vol. 192). New York: Back Bay Books.

[8] Waterman, R. H., Peters, T. J., \& Phillips, J. R. (1980). Structure is not organization. Business horizons, 23(3), 1426.

[9] Schneiderman, A. M. (1999). Why balanced scorecards fail. Journal of strategic performance measurement, 2(11).

[10] Porter, M. E. (2008). The five competitive forces that shape strategy. Harvard business review, 86(1), 25-40.

[11] Henderson, B. D. (1979). The product portfolio: growth share matrix of the Boston Consulting Group. The strategy process: Concepts, contexts, cases, 678680.

[12] Porter, M. E., \& Millar, V. E. (1985). How information gives you competitive advantage.

[13] Hax, A. C., \& Wilde, D. L. (2003). The delta model-a new framework of strategy. Journal of Strategic Management Education, 1(1), 1-21.

[14] Barney, J. B. (2001). Resource-based theories of competitive advantage: A tenyear retrospective on the resource-based view. Journal of management, 27(6), 643650.

[15] Prahalad, C. K., \& Hamel, G. (1997). The core competence of the corporation. En Foss, 235-56.

[16] Pejman Makhfi (2005). Heptalysis - The Venture Assessment Framework. Venture Choice, Inc. Retrieved 22/08/2017.

[17] Sondhi K. Rakesh (1999), Total Strategy. Airworthy publications International.

[18] Checkland, P. B., and Scholes, J. (1990). Soft Systems Methodology in Action, Wiley, New York.

[19] Hunt, David, Bacon, Liz (2009). VPEC-T: A Way to Bridge the Gap Between Business and IT. Enterprise Architecture Conference Europe 2009. Retrieved 2017-
08-14.

[20] Angehrn, A. (1997). Designing mature Internet business strategies: the ICDT model. European Management Journal, 15(4), 361-369.

[21] Reshma, Aithal, P S, Shailashree, V T, Sridhar Acharya, P. (2015). An Empirical study on working from home - A popular E-business model. International Journal of Advance and Innovative Research, $2(2$ (I)), 12-18.

DOI http://doi.org/10.5281/zenodo.164429.

[22] Aithal, P. S., Shailashree, V. T., \& Suresh Kumar, P. M. (2015). Application of ABCD Analysis Model for Black Ocean Strategy. International Journal of Applied Research (IJAR), 1(10), 331-337. DOI: http://doi.org/ 10.5281/zenodo.163424.

[23] Aithal, P. S., Shailashree, V. T., \& Suresh Kumar, P. M. (2016). ABCD analysis of Stage Model in Higher Education. International Journal of Management, IT and Engineering (IJMIE), 6(1), 11-24. DOI: $\quad$ http://doi.org/10.5 281/zenodo.154233.

[24] Aithal, P. S., Shailashree, V.T., \& Suresh Kumar, P. M. (2016). Analysis of NAAC Accreditation System using ABCD framework. International Journal of Management, IT and Engineering (IJMIE), 6(1), $\quad 30 \quad-\quad 44 . \quad$ DOI: http://doi.org/10.5281/zenodo.154272.

[25] Aithal, P. S., Shailashree, V. T., \& Suresh Kumar, P. M. (2016). Application of ABCD Analysis Framework on Private University System in India. International Journal of Management Sciences and Business Research (IJMSBR), 5(4), 159170. DOI http://doi.org/10.5281/zenodo.161111.

[26] Aithal, P. S., Shailashree, V. T., \& Suresh Kumar, P. M., (2016). The Study of New National Institutional Ranking System using ABCD Framework. International Journal of Current Research and Modern 
Education (IJCRME), 1(1), 389 - 402. DOI

: http://doi.org/10.5281/zenodo.161077.

[27] Aithal, P. S., Shailashree, V. T. \& Suresh Kumar, P. M., (2016). Analysis of ABC Model of Annual Research Productivity using ABCD Framework. International Journal of Current Research and Modern Education (IJCRME), 1(1), 846-858. DOI : http://doi.org/10.5281/ zenodo.62022.

[28] Shubhrajyotsna Aithal, \& Aithal, P. S., (2016), ABCD analysis of Dye doped Polymers for Photonic Applications. IRAInternational Journal of Applied Sciences, 4(3), 358-378. DOI :http://dx.doi.org/10.21013/jas.v4.n3.p1.

[29] Aithal, P. S. \& Suresh Kumar, P. M. (2016). CCE Approach through ABCD Analysis of 'Theory A' on Organizational Performance. International Journal of Current Research and Modern Education (IJCRME) 1(1), 169-185.

DOI: http://dx.doi.org/10. 5281/zenodo.164704.

[30] Varun Shenoy, \& Aithal P. S., (2016). ABCD Analysis of On-line Campus Placement Model, IRA-International Journal of Management \& Social Sciences, 5(2), 227-244. DOI: http://dx.doi.org/10.21013/jmss.v5.n2.p3.

[31] Aithal, P. S., Shailashree V. T. \& Suresh Kumar P.M. (2016). Factors \& Elemental Analysis of Six Thinking Hats Technique using ABCD Framework. International Journal of Advanced Trends in Engineering and Technology (IJATET), 1(1), 85-95. DOI

http://doi.org/10.5281/zenodo.240259.

[32] Aithal, P. S. (2017). ABCD Analysis of Recently Announced New Research Indices. International Journal of Management, Technology, and Social Sciences (IJMTS), 2(1), 65-76. DOI: http://doi.org/10.5281/zenodo. 583644.

[33] Aithal, P. S. (2017). Factor Analysis based on ABCD Framework on Recently Announced New Research Indices, International Journal of Management, Technology, and Social Sciences (IJMTS), 1(1), 82-94. DOI: http://dx.doi.org/10.5281/zenodo.584105.

[34] Aithal, P. S., Shailashree, V. T., Suresh Kumar, P. M. (2015). A New ABCD Technique to Analyze Business Models \& Concepts. International Journal of Management, IT and Engineering (IJMIE), 5(4), 409 - 423. DOI : http://doi.org/10.5281/zenodo.61652.

[35] Rogers, E. M., (1995). Diffusion of Innovation. The Free Press, NY.

[36] Aithal P. S. and Varambally, K. V. M. (2006). Security Issues in Online Financial Transactions with Special Reference to Banking Industry. In Quality in Service Sector and Managerial Challenges, Allied Publisher Pvt. Ltd. 2006, ISBN: 81-7764992-2, pp 103- 114.

[37] Aithal, P. S., \& Varambally, K. V. M. (2009). Mobile Business Technology and Business Proliferation of Banks - A futuristic Approach. Amity Business Review - an Indian Journal, 10(1), 9-25.

[38] Aithal, P. S., \& Shubhrajyotsna Aithal, (2015). A review on Anticipated Breakthrough Technologies of 21st Century. International Journal of Research \& Development in Technology and Management Sciences, 21(6), 112-133. DOI: http://doi.org/10.5281/zenodo. 61617.

[39] Aithal, P. S., \& Shubhrajyotsna Aithal, (2015). An Innovative Education Model to realize Ideal Education System. International Journal of Scientific Research and Management (IJSRM), 3(3), 2464 2469.

DOI: http://doi.org/10.5281/zenodo.61654.

[40] Sridhar Acharya, P. \& Aithal, P. S. (2016). Clean Energy for Poor - A Changing Scenario. International Journal of Advanced Trends in Engineering and Technology (IJATET), 1(1), 129-133. DOI : http://doi.org/10.5281/zenodo.240287.

[41] Aithal, P. S., Shailashree V. T \& Suresh Kumar P. M., (2016). Analysis of ABC 
Model of Annual Research Productivity using ABCD Framework. International Journal of Current Research and Modern Education (IJCRME), 1(1), 846-858. DOI : http://doi.org/10.528 1/zenodo.62022.

[42] Aithal, P. S. \& Suresh Kumar, P. M. (2016). Opportunities and Challenges for Private Universities in India. International Journal of Management, IT and Engineering (IJMIE), 6(1), 88-113. DOI : http://doi.org/10.5281/zenodo. 161157.

[43] Sridhar Acharya, P. \& Aithal, P. S., (2016). Concepts of Ideal Electric Energy System for production, distribution and utilization. International Journal of Management, IT and Engineering (IJMIE), 6(1), 367-379. DOI http://doi.org/10.5281/zenodo.161143.

[44] Padmanabha Shenoy, \& Aithal, P. S., (2016). A Study on History of Paper and possible Paper Free World. International Journal of Management, IT and Engineering (IJMIE), 6(1), 337-355. DOI : http://doi.org/10.5281/zenodo. 161141.

[45] Aithal, P.S., (2015). Comparative Study on MBA Programmes in Private \& Public Universities - A case study of MBA programme plan of Srinivas University, International Journal of Management Sciences and Business Research (IJMSBR), 4(12), 106-122. DOI : http://doi.org/10.5281/zenodo.163884.

[46] Aithal P. S., \& Shubhrajyotsna Aithal (2016). Impact of On-line Education on Higher Education System. International Journal of Engineering Research and Modern Education (IJERME), 1(1), 225235. DOI : http://doi.org/ 10.5281/zenodo.161113.

[47] Aithal P. S., and Suresh Kumar P. M., (2016). Analysis of Choice Based Credit System in Higher Education. International Journal of Engineering Research and Modern Education (IJERME), 1(1), 278284. DOI : http://doi.org/ 10.5281/zenodo.161046.
[48] Varun Shenoy and Aithal P. S., (2016). Changing Approaches in Campus Placements - A new futuristic Model, International Journal of Scientific Research and Modern Education (IJSRME), 1(1), 766 - 776. DOI : http://doi.org /10.5281/zenodo.160966.

[49] Prithi Rao, and Aithal, P.S. (2016). Green Education Concepts \& Strategies in Higher Education Model, International Journal of Scientific Research and Modern Education (IJSRME), 1(1), 793-802. DOI : http://doi.org/ 10.5281/zenodo.160877.

[50] Aithal, P. S. \& Shubhrajyotsna Aithal (2016). Ekalavya Model of Higher Education - an Innovation of IBM's Big Data University. International Journal of Current Research and Modern Education (IJCRME), 1(2), 190-205. DOI: http://dx.doi.org/10.5281/ZENODO.1 $\underline{98704}$.

[51] Aithal, P. S. \& Shubhrajyotsna Aithal, (2016). A New Model for Commercialization of Nanotechnology Products and Services. International Journal of Computational Research and Development, 1(1), 84-93. DOI : http://doi.org/10.5281/zenodo.163536. 